\title{
In memoriam - Prof. Dr. dr. Saptawati Bardosono, MSc
}

Received 26 February 2022 Accepted 26 February 2022 Published: 28 February 2022

Link to DOI:

10.25220/WNJ.V05.i2.0001

\author{
Pittara Pansawira ${ }^{1,2}$, Luciana B. Sutanto ${ }^{1,2}$ \\ 1. World Nutrition Journal \\ 2. Indonesian Nutrition Association, Indonesia
}

\begin{tabular}{l} 
Abstract \\
The editorial is dedicated to honor the passing of Prof. Saptawati Bardosono on October 15 $5^{\text {th, }} 2021$ \\
\hline Keywords in memoriam; saptawati bardosono; world nutrition journal
\end{tabular}

Citation: Pansawira P, Sutanto LB. In memoriam-Prof. Dr. dr. Saptawati Bartdosono, MSc. World Nutrition Journal.2022 Feb 28 5(2):i-ii.

\section{In memoriam}

The passing of Prof. Saptawati Bardosono on October $15^{\text {th }}$ last year was a great sadness and loss for the entire scientific community, especially nutrition-related. It was also an immeasurable grief for us, the editorial team of World Nutrition Journal.

Her passion in nutrition began when she served as a physician in a remote village of Papua, back in the early '80s. Afterward, Prof. Saptawati Bardosono dedicated her whole life researching and educating both medical professionals and society in relation to nutritional knowledge and promotion of living healthier. She was particularly devoted to child's nutrition to prevent stunting.

She had done numerous research which included studies in nutrition for pregnant and lactating women, infants, toddlers, pre-school children, and

\section{Corresponding author:}

dr. Pittara Pansawira, MGizi

World Nutrition Journal. Indonesian Nutrition Association,

Indonesia

Email : pittarapansawira@gmail.com adults; both clinical and community-related. She spoke in numerous seminars and established many workshops, not to mention writing and publishing many books, modules, and articles. She was also acting as the secretary of Indonesian Nutrition Association (Perhimpunan Nutri Indonesia).

In 2016, she founded the World Nutrition Journal, the official journal of Indonesian Nutrition Association, as an open access journal for the expansion of nutrition-related knowledge and acts as a media, both for medical students and experts, to publish their researches, in which she acted as the editor-in-chief. ${ }^{1}$

No words can describe how dedicated and brilliant her ideas were. We will cherish not only for her memory, education, advices, and creativities, but also her warmth, generosity, and kindness. She was the irreplaceable mentor, our teacher, and our mother-figure with a hearty laugh and caring personality. As her students, colleagues, and friends, let us continue our duty to never quit in pursuing knowledge for the advancement of nutrition science. 


\section{Open Access}

This article is distributed under the terms of the Creative Commons Attribution 4.0 International Licence

(http://creativecommons.org/licenses/by/4.0/), which permits unrestricted use, distribution, and reproduction in any medium, provided you give appropriate credit to the original author(s) and the source, provide a link to the Creative Commons license, and indicate if changes were made.

\section{References}

1. Bardosono S. The Importance of Nutrition Journal Publication. World Nutrition Journal. 2017 Sep 6;1(1):i-i. 